\title{
Biodeterioration Affecting Efficiency and Lifetime of Plastic-Based Photovoltaics
}

Schmidt, Felix; Zimmermann, Yannick Serge; dos Reis Benatto, Gisele Alves; Kolvenbach, Boris A.; Schäffer, Andreas; Krebs, Frederik C.; van Hullebusch, Eric D.; Lenz, Markus

\section{Published in:}

Joule

Link to article, DOI:

10.1016/j.joule.2020.08.015

Publication date:

2020

Document Version

Publisher's PDF, also known as Version of record

Link back to DTU Orbit

Citation (APA):

Schmidt, F., Zimmermann, Y. S., dos Reis Benatto, G. A., Kolvenbach, B. A., Schäffer, A., Krebs, F. C., van Hullebusch, E. D., \& Lenz, M. (2020). Biodeterioration Affecting Efficiency and Lifetime of Plastic-Based Photovoltaics. Joule, 4(10), 2088-2100. https://doi.org/10.1016/j.joule.2020.08.015

\section{General rights}

Copyright and moral rights for the publications made accessible in the public portal are retained by the authors and/or other copyright owners and it is a condition of accessing publications that users recognise and abide by the legal requirements associated with these rights.

- Users may download and print one copy of any publication from the public portal for the purpose of private study or research.

- You may not further distribute the material or use it for any profit-making activity or commercial gain

- You may freely distribute the URL identifying the publication in the public portal 


\title{
Persoctive \\ Biodeterioration Affecting Efficiency and Lifetime of Plastic-Based Photovoltaics
}

\author{
Felix Schmidt, 1,2 Yannick-Serge Zimmermann, ${ }^{1,2}$ Gisele Alves dos Reis Benatto, ${ }^{3}$ Boris A. Kolvenbach, ${ }^{1}$ \\ Andreas Schäffer, ${ }^{2}$ Frederik C. Krebs, ${ }^{4}$ Eric D. van Hullebusch, ${ }^{5}$ and Markus Lenz ${ }^{1,6, *}$
}

\section{SUMMARY}

The low environmental impact of electricity generation using solar cells crucially depends on high energy-conversion efficiencies, long lifetimes, and a minimal energy and material demand during production. Emerging thin-film photovoltaics such as perovskites on plastic substrates could hold promises to fulfill all these requirements. Under real-world operating conditions, photovoltaic operation is challenged by biological stressors, which have not been incorporated for evaluation in any test. Such stressors cause biodeterioration, which impairs diverse, apparently inert materials such as rock, glass, and steel and therefore could significantly affect the function and stability of plastic-based solar cells. Given that different photovoltaic technologies commonly use similar materials, the biodeterioration mechanisms reviewed here may possibly affect the efficiency and lifetimes of several technologies if they occur sufficiently faster (during the expected lifetime of photovoltaics). Once the physical integrity of uppermost module layers is challenged by biofilm growth, microbially mediated dissolution and precipitation reactions of photovoltaic functional materials are very likely to occur. The biodeterioration of substrates and seals also represents emission points for the release of potentially harmful photovoltaic constituents to the environment.

\section{INTRODUCTION}

Solar energy is expected to become a dominant source of renewable energy in the near future. A general consensus exists that the transition to a reliable, publicly accepted, sustainable, and competitive energy system is one of the "grand challenges" that modern society must tackle. In this regard, the United Nations' (UN) sustainable development goals call for affordable and clean energy, economic growth, and the development of sustainable cities and communities. ${ }^{1}$ Green energy generation from traditional silicon photovoltaics (PVs) is already a mature technology, delivering most of the overall capacity of more than 670 TWh worldwide in $2018 .{ }^{2}$ Apart from seeing consistently high growth rates, the technology accords with the UNs and the International Energy Agency's general and specific sustainable development targets, respectively. ${ }^{1,2}$ Among PV technologies, monocrystalline, polycrystalline, and amorphous thin-film silicon solar cells account for the highest share of installed capacity. However, after 40 years of development and optimization, the silicon-based technology is approaching its limits with respect to efficiency enhancement on the one hand and cost minimization on the other. Second-generation thin-film PV technologies such as CdTe or CIGS have been developed within the last $20-30$ years and acquired a market share of roughly $10 \%{ }^{3}$ However, to address

\section{Context \& Scale}

Upon exposure to the natural environment, not even diamonds are forever. In real-world operating conditions, photovoltaics are affected by biodeterioration through biofilm growth that impairs diverse, apparently inert materials, such as rock, glass, and steel.

Biodeterioration goes beyond obstructing incoming light and affecting energy conversion; it challenges the physical integrity of substrates. This phenomenon may thus heavily degrade primarily plastic-based thin-film photovoltaics. Following initial degradation, functional layers can undergo microbially mediated dissolution and precipitation, thereby affecting the lifetimes of such solar cells. Biofilm development also influences how potentially harmful photovoltaic constituents (e.g., lead from perovskites) are released to the environment. Despite the considerable potentiality of these detrimental effects, however, they are yet to be systematically studied. Given that different types of solar cells commonly use similar materials, the biodeterioration mechanisms reviewed here may affect several technologies. This paper provides a comprehensive review of the colonization of photovoltaics by sub-aerial biofilms and their potential negative impacts on 
limitations in the application (rigidity, weight issues, and opaqueness) of the first and second-generation PVs, efforts are made to develop the so-called third-generation PVs based on thin films of new photoactive materials. ${ }^{4,5}$ Such emerging thin-film cells can be manufactured from inexpensive starting materials as light-weight, mechanically flexible, and semi-transparent thin films, ${ }^{6-8}$ possibly through cost- and energy-effective automated roll-to-roll (R2R) printing on, for instance, polyethylene terephthalate (PET) or polyethylene naphthalate (PEN) films. ${ }^{9}$ These technologies also require low energy and few materials during manufacturing, ${ }^{10,11}$ and their potential flexibility and transparency open up additional areas of application (e.g., building-integrated PVs or consumer electronics ${ }^{12-14}$ ).

Among different third-generation technologies, two innovations hold a particular promise to indeed serve large-scale power production: perovskites and organic PVs (OPVs). ${ }^{15-17}$ From a technical point of view, perovskites (containing organic or inorganic lead halide salts) have attracted unprecedented attention due to extraordinarily high power-conversion efficiencies (PCEs) achieved. ${ }^{18,19}$ Within a decade after (re)discovery, ${ }^{20}$ the best-performing perovskite cells have already reached a certified PCE of $25.2 \%$, thus exceeding the performance of other PV technologies, such as a-Si or CdTe. ${ }^{21}$ Conversely, there is low energy and chemical demand for the production of organic photovoltaics, and, despite their lower PCEs, OPVs may have an energy payback time potentially as short as one day. ${ }^{22}$

The functional unit of the third-generation PV is made up of (typically) five layers. These layers are a photoactive material, which is required for photon absorption and charge-carrier generation; two charge-specific extraction layers, which are incorporated for charge separation and transport; and two electrodes located at the top and bottom for contacting complete a general device stack. A variety of materials, both organic and inorganic, can be used to fabricate each of these layers, but many PV technologies are composed of similar materials. Electrode materials include $\mathrm{Ag}, \mathrm{Au}, \mathrm{Al}, \mathrm{ZnO},{ }^{23,24}$ or indium tin oxide (ITO), the most predominant transparent contact. ${ }^{25}$ For charge transport, metal oxides such as $\mathrm{ZnO}, \mathrm{TiO}_{2}$, and $\mathrm{NiO}_{x}$ are employed frequently. ${ }^{26-28}$ The device stack is then sealed and encapsulated using either glass for rigid solar cells or polymeric materials, such as PET or PEN. ${ }^{29-31}$ Material selection depends on the substrate requirements of solar cells. Plastic-based solar cells, for example, require materials compatible with R2R and sheet-to-sheet processing, ${ }^{32-38}$ whereas glass-based PVs consist of materials that can be processed through higher-temperature and pressure methods, such as chemical vapor deposition or atomic layer deposition (a combination of materials in perovskites are reviewed in Jung and Park; ${ }^{39}$ and those in OPVs are reviewed in Zimmermann et al.). ${ }^{40}$ Nonetheless, for an emerging thin-film PV, the fabrication can be carried out under a significantly lower temperature compared with, for example, the first-generation PV.

\section{LABORATORY TESTS FOR EXTRAPOLATING EFFICIENCY AND OPERATIONAL LIFETIME IN THE FIELD}

Common to most plastic-based PVs is an operational lifetime that is relatively shorter than that of PV technologies with the glass substrate, such as the crystalline silicon PV. This discrepancy has driven the initiation of numerous laboratory studies to deal with potential failure mechanisms and formulate solutions. ${ }^{41-47}$ Tests were developed to simulate outdoor stressors, such as temperature, humidity, and salt accumulation in an accelerated manner. ${ }^{48-50}$ Such design qualifications, such as damp-heat tests, for instance, could aid in the extrapolation of PV lifetime in relation to environmental stressors. In these tests, PV devices are exposed to elevated photovoltaics. We discuss why abiotic laboratory tests for PV efficiency and lifetime poorly reflect the stress PVs suffer in outdoor conditions. We then summarize the knowledge on soiling as well as microbial-, algal-, and fungal growth on PVs. This is followed by a discussion of the physical mechanisms that affect PV efficiency via soiling and photon competition as well as chemical and biological mechanisms (plastic degradation, microbially induced dissolution, and precipitation reactions) that can affect active layers and thus the lifetime of PVs in the field.
${ }^{1}$ Institute for Ecopreneurship, School of Life Sciences, University of Applied Sciences and Arts Northwestern Switzerland, Hofackerstrasse 30, 4132 Muttenz, Switzerland

2Institute for Environmental Research, RWTH Aachen University, Worringerweg 1, 52074 Aachen, Germany

${ }^{3}$ Department of Photonics Engineering, Technical University of Denmark, Frederiksborgvej 399, 4000 Roskilde, Denmark 4Elitescience, Bagsværdvej 147B, 2800 Lyngby, Denmark

5 Institut de Physique du Globe de Paris, Université de Paris, CNRS, 75005 Paris, France

${ }^{6}$ Sub-Department of Environmental Technology, Wageningen University, 6700 AA, Wageningen, the Netherlands

*Correspondence: markus.lenz@fhnw.ch

https://doi.org/10.1016/j.joule.2020.08.015 


\section{$\boldsymbol{\infty}$ CellPress}

temperatures (e.g., $85^{\circ} \mathrm{C}$ ) and a high relative humidity (e.g., 85\%) in the dark for prolonged periods. These stressors induce accelerated aging, as observed in the field, ${ }^{51}$ although one can argue how well these accelerated aging tests simulate actual outdoor conditions (daily and seasonal thermal cycles, rain, hail, etc.).

On an yearly basis, the International Summit for Organic and Hybrid Photovoltaics Stability discusses the expected lifetimes of OPVs and perovskite-based solar cells in accordance with established standards. ${ }^{46,52}$ These discussions have made detailed stability reviews available and enabled the storage of data in an extensive database. ${ }^{53,54}$ Data on OPVs, for example, indicate that the degradation of P3HT (a common p-type semiconductor) is associated with the loss of alkyl and thiophene groups upon P3HT photo- and thermo-oxidation. ${ }^{55} \mathrm{R}-\mathrm{SO}_{x}$ species are detected in active layers (containing P3HT) after full solar illumination. PEDOT:PSS (another frequently used conductive polymer) is highly hydrophilic and, upon exposure to moisture, undergoes conformational changes perturbing device performance. Also, it can react chemically in the air when exposed to UV light, ${ }^{56}$ and this photooxidation of conjugated PEDOT:PSS chains reduce electrical conductivity. For the perovskite $\mathrm{PV}$, the failure of active materials and devices is a considerable problem that may be influenced by extrinsic (oxygen, light, moisture, and temperature) and intrinsic (thermal and electric fields) degradation mechanisms, as reviewed in Berhe et al., ${ }^{57}$ and Niu et al. ${ }^{58}$ A number of outdoor lifetime tests are available for OPVs, ${ }^{48}$ but the first inter-laboratory outdoor test series for perovskite PVs has only recently been published. ${ }^{59}$ Approaches that use a "multi-measurement kit" are an option to save costs and space for monitoring, as these methods require only electrical connections and power sources. This kit can then be used for inter-laboratory comparisons in a "round-robin" approach and has been employed within the OPV community (e.g., Larsen-Olsen et al. ${ }^{60}$ and Corazza et al. ${ }^{61}$ ) Notwithstanding the possibility of assessing the effects of a combination of actual degradation stressors, outdoor experiments are time-consuming as their development is often excessively slow to keep pace with rapid technological advancements in real-world applications.

\section{CURRENT UNDERSTANDING OF SOILING ON PV PANELS}

Photovoltaics deployed in the field suffer from "soiling," which is a term used to describe the accumulation of snow, abiotic materials (mineral dust, soot particles, and aerosols), and biotic factors (leaves, fungi, spores, pollen, and bird droppings) on PV panels. Soiling is an important problem for the PV industry and has become a pressing impediment to truly large-scale deployment. ${ }^{62,63}$ Deposited materials absorb, scatter, and reflect incoming sunlight, thus reducing the intensity that reaches the active part of a solar cell. ${ }^{64}$ Airborne dust concentration, relative humidity, surface temperature, precipitation, and wind speed have also been identified as major drivers of soiling rates ${ }^{65}$ and references herein). Much work has been done in extremely arid climates, where dust deposition can result in considerable losses in power production (as much as $0.1 \%$ per day ${ }^{66}$ ). In moderate climates (e.g., Belgium), dust settling on PV modules is not as severe as that occurring in arid climates. ${ }^{67}$ Nevertheless, a constant power loss of $3 \%$ to $4 \%$ was found even at an optimal tilt angle. In arid climates, soiling rates are critically influenced by self-cleaning through particle rebound (particles bouncing off a surface during dust deposition) and particle resuspension (removal of particles adhering to surfaces by wind), whereas in humid regions, such rates are affected by self-cleaning through the rain. Regular module cleaning and coatings ${ }^{68,69}$ have been used as potential mitigation strategies for soiling.

Most of the work on the fundamental aspects of the mechanisms and effects of soiling on power production has been carried out under laboratory, dry, and abiotic 
conditions. Adequate exploration has also been devoted to soiling by abiotic factors (e.g., dust, dirt, and snow). ${ }^{64,70}$ Among the biotic stressors considered to date, the soiling contributors mostly discussed are pollen and spores, but microbial biofilms and their negative impact on PV performance are still largely overlooked. ${ }^{71}$ Up to 2015, only one of the nearly 200 dust and soiling PV papers published in previous years focused on soiling-causing microorganisms, ${ }^{72}$ and only a handful of studies on these microorganisms were available for review in the current work.

Sub-aerial biofilm (SAB) colonization may exert manifold negative effects and influence both PV efficiency and lifetime. SAB colonization causes biofilm growth, light scattering, and light reflection, which in turn, reduce the efficiency of PV installation. ${ }^{73}$ Some microorganisms also produce pigments either to shield themselves from radiation damage or carry out photosynthesis, thereby competing against PV absorbers for photon use. ${ }^{73}$ Furthermore, the physical integrity of substrates (glass and plastic) and sealants may be challenged by the growth of fungal hyphae, the secretion of exo-enzymes, and the corrosive action of metabolic intermediates and end products. Charge transport and the functioning of absorber and electrode materials can be challenged by biologically induced precipitation reactions. Such detrimental effects of SABs are collectively referred to as "biodeterioration"74,75 are reviewed here. Despite knowledge from other fields and materials related to PVs, the above-mentioned effects have neither been quantified nor considered in the development of emerging thin-film PVs. In contrast, accelerated aging tests are typically conducted using simplified media (i.e., pure water) and without the presence of biomass.

\section{COLONIZATION OF PV PANELS BY SABs AFFECTING PV EFFICIENCY}

Microbes are ubiquitous settlers on every solid surface on the earth. ${ }^{75,76}$ The term $\mathrm{SAB}$ originally referred to microbial communities that develop on the interface between minerals and the atmosphere, ${ }^{76}$ but nowadays the designation covers microorganisms that colonize virtually all solid-atmosphere interfaces. The complex structure of an SAB encompasses non-living, extracellular polymeric substances (EPS) and, as a whole, provides a diversity of habitats on a small scale, thus giving micro-consortia ecologic niches and conferring protection against environmental stressors (Figure 1), such as desiccation and UV radiation. ${ }^{77}$

SAB colonization represents an important stage in primary succession in terrestrial ecosystems and contributes substantially to the "weathering" of rock-forming minerals. ${ }^{78}$ As "rock-eating microbes," SABs ultimately lead to the transformation and dissolution of mineral phases, thereby supplying nutrients to all other organisms. The formation of SABs is initiated as soon as the material is placed under outdoor conditions, whereas maturation will depend on a multitude of factors (e.g., geographic location, temperature, precipitation, nutrients, competition for resources, etc.). SABs do not simply cover hard surfaces; they interact with them in myriad ways and bind to underlying substrates. This adhesion and protection against dehydration are further aided by the secretion of extracellular mucilage during the biofilm maturation, while surface weathering is brought forth by microbially produced low molecular weight organic acids and acidic polysaccharides. ${ }^{79,80}$ SABs may have a detrimental effect on the physical integrity of various seemingly inert materials, such as concrete, glass, sandstone, and even steel. Next to physical and chemical damage, SABs cause considerable aesthetic damage on building materials. ${ }^{81-85}$ Biocorrosion from SAB colonization has been estimated to account for $20 \%$ of all corrosion and may account for costs as much as tens of billions US dollars annually. ${ }^{86-88}$ 


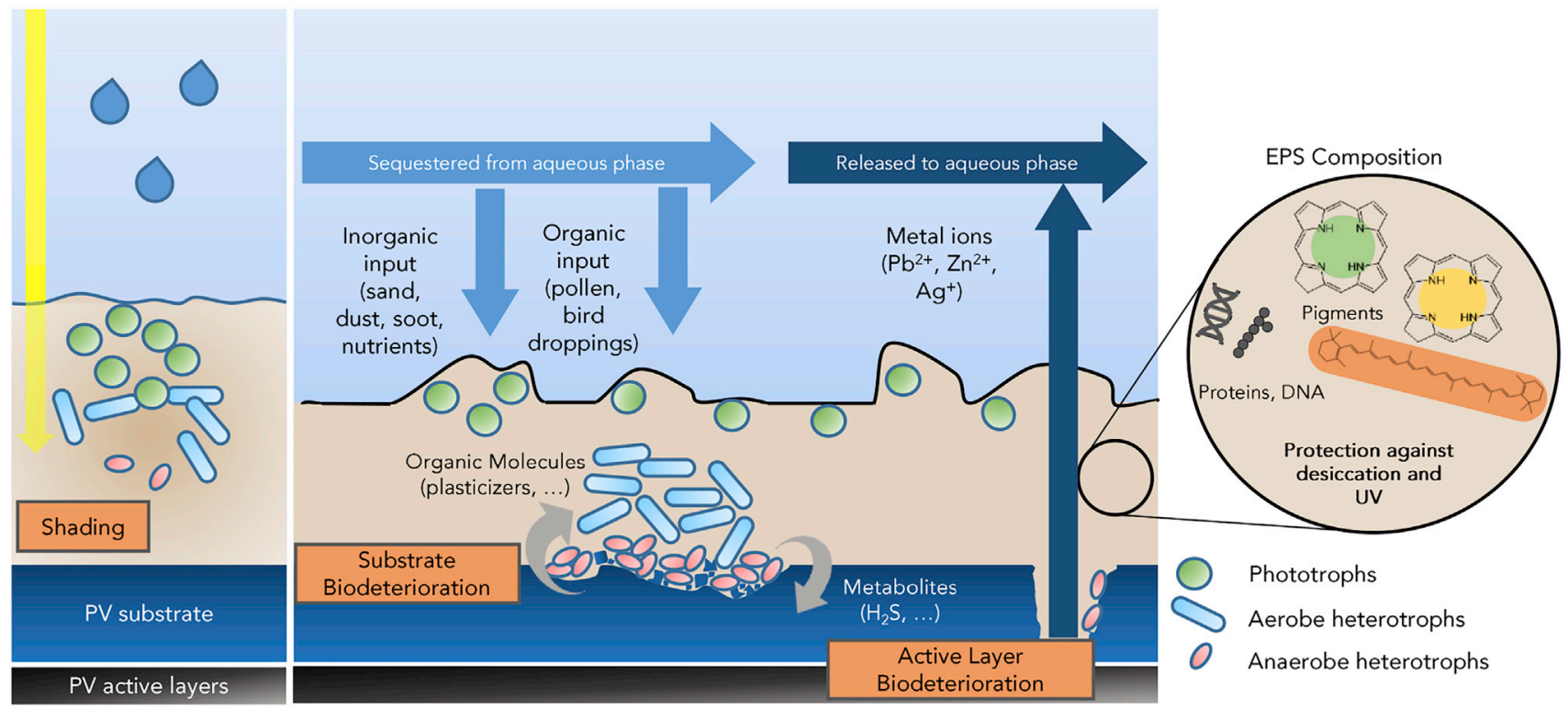

Figure 1. Photovoltaic Biodeterioration Mechanisms by SAB Colonization

(A) The biofilm matrix protects microorganisms within the pristine biofilm against environmental stressors such as UV radiation and desiccation.

(B) The presence of a sub-aerial biofilm enables the capture of various molecules and their sequestration from the aqueous phase. The degradation of the substrate and active layers can lead to the release of PV constituents into the environment.

(C) EPS-derived chromophores can absorb photons from the visible range for photosynthesis and thereby decrease PV quantum efficiency. Adapted from Flemming et al 2016. ${ }^{7}$

Studies recently uncovered information on the composition of SAB communities that develop on silicon PV panels. For example, research conducted in São Paulo, Brazil, indicated that under humid, subtropical conditions, SABs were shown to develop on glass substrates of crystalline Si modules. ${ }^{89}$ Here, the presence of a diverse community of fungi, algae, bacteria, and cyanobacteria significantly reduce power after 6 (minus 7\%) and 18 months (minus 11\%) of exposure. Martin-Sanchez et al. used qPCR-based methods to quantify the fungi, bacteria, and phototrophs on PV panels and found that fungal biomass clearly dominates in all analyzed PV modules, ${ }^{72}$ whereas bacteria and phototrophs proliferate to a much lower extent in a marine west coast climate (Berlin and Karlsruhe, Germany). Under high irradiation conditions (as with a case in southern Spain; Mediterranean climate), a community of $\sim 500$ species was found to proliferate on a solar panel with most of the species belonging to drought-, heat-, and radiation-adapted bacterial genera, and solar irradiation-adapted epiphytic fungi. ${ }^{90}$ These results align with those of another study that found a highly diverse community of extremophile or extremotolerant bacteria, among which Hymenobacter spp., radiation-resistant Modestobacter marinus, Kineococcus radiotolerans, and Alternaria alternata dominated. ${ }^{91}$ In this study conducted in Valencia, Spain, and Berkeley, California in the USA, the assessed metabolomes were very similar in composition. This similarity was attributed to the comparable climatic conditions of the two same-latitude locations, and thus, selective pressures.

As outlined above, soiling by abiotic factors (dust, dirt, snow, etc.) is well-studied in arid climates (reviewed in e.g., Ilse et al. ${ }^{65}$ and Costa et al. ${ }^{70}$ ), but some data on more humid climates are also available. ${ }^{67}$ Interestingly, increased relative humidity and moisture content on a surface can dramatically decrease particle rebound, and an 
effective particle "capture" occurs at relative humidity levels above $75 \% .{ }^{92}$ Such capture mechanisms may be applicable not only to pollen and spores that have been regarded (but not systematically assessed) as biotic factors to date but also to inocula for SAB colonization. Initial colonization may proceed from wind-blown inocula (e.g., as travelers on pollen or spores, leaves ${ }^{93-95}$ ) and bird droppings. Possibly, the first step in the colonization of PV surfaces is carbon fixation by photoautotrophs followed by the development of more complex communities of chemoheterotrophic organisms, including fermentative bacteria and fungi ${ }^{73,89}$ (Figure 1).

Counterintuitively, SAB colonizing solid-atmospheric interfaces are not entirely aerobic. $^{77}$ The existence of redox gradients in SABs results from the fact that both oxidative and reductive parts of elemental cycles can be thermodynamically favored. For instance, SABs on stone monuments host almost complete nitrogen (nitrogen-fixing cyanobacteria, nitrifying and denitrifying bacteria) and sulfur cycles (sulfur-oxidizing bacteria and sulfate-reducing bacteria [SOB and SRB, respectively]) as well as autotrophic carbon fixation and other processes. ${ }^{96}$ On the outdoor stonework affected by atmospheric sulfur pollution, ${ }^{97}$ the bacterial communities active in sulfur cycling are composed mainly of cyanobacteria, anoxygenic phototrophic sulfur bacteria, and aerobic SOB and SRB. ${ }^{97}$ The growth of SRB and SOB is fueled by organic carbon produced by cyanobacteria during photosynthesis. SOBs consume oxygen and allow for the reducing environments necessary for SRB and anoxygenic phototrophic sulfur bacteria proliferation. As a result, a mature SAB on a PV installation can represent a complex food web, where elements are cycled internally.

Considering that a SAB consists mostly of water and EPS, ${ }^{98}$ colonization by SABs may increase soiling rates, with the bacteria acting similar to a "sticky tape." Some strategies against soiling are aimed at increasing hydrophilicity to facilitate the "self-cleaning" effect of rain. ${ }^{99}$ Although effective in laboratory (abiotic) conditions, SAB colonization on outdoor solar panels may deliver the glue for "cementation" that is currently thought to arise from the combination of mineral deposits. Under this phenomenon, moisture cycles from dew drive the formation of strong bonds of adhesion with the module surface. ${ }^{65}$ The deposition of any material decreases incoming light via scattering, reflection, and absorption to some extent and thus reducing PV efficiency. An aspect of some microbes in SABs, however, is the biosynthesis of pigments that absorb light in the visible spectrum. Pigments serve several physiological functions, of which the most paramount is photosynthesis, but they also confer protection from solar radiation and oxidative damage. ${ }^{76}$ In this regard, solar radiation is understood as an environmental stressor that drives the development of UV resistance in strains that take the form of pigments. ${ }^{100}$ All pigments share a chromophoric character that is based on the absorption of a certain range of the visible light. PVs depend as well on the use of photons with a large overlapping spectrum (Figure 2), pointing to the inherent "competition for photons" between biota and photoactive materials. Prokaryotes, such as cyanobacteria and eukaryotic algae, are both abundant in SABs ${ }^{101,102}$ and contain porphyrin-based chlorophyll a, whereas purple bacteria contain bacteriochlorophyll a or b. ${ }^{103}$

Chlorophylls ( $a, b$, bacteriochlorophyll a) differ primarily in substituents and double bonds around porphyrin-like rings when endowing these pigments different absorption properties (Figure 2). In micro-colonial fungi, which are common inhabitants of $\mathrm{SAB}$, protection from UV is conferred by carotenoids and melanins $\left({ }^{76}\right.$ and references herein). Melanins, or hydrophobic pigments of high molecular weight, ${ }^{105}$ confer protection against UV radiation and complete the antioxidant pathway in some phytopathogens. ${ }^{106}$ Carotenoids consist of a wide array of biomolecules produced by 


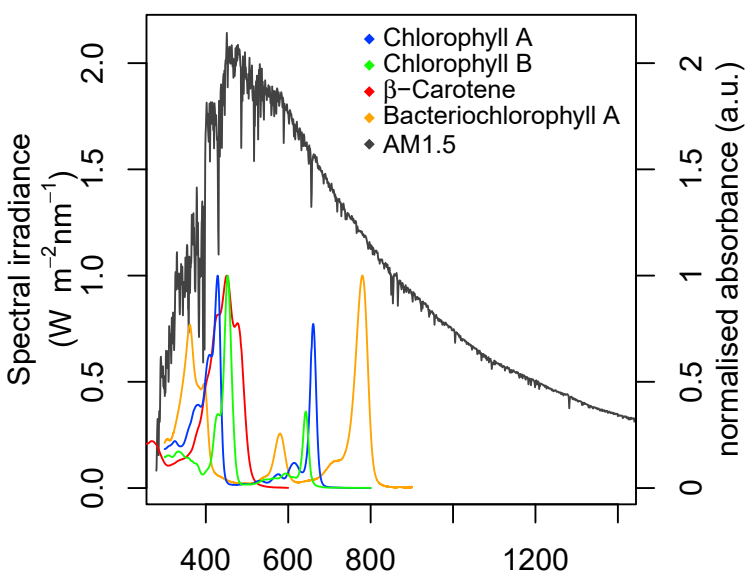

Wavelength $(\mathrm{nm})$

Figure 2. Photon Competition in the Visible Solar Spectrum

Absorbance spectra for common pigments produced by SABs and the global standard solar spectrum AM1.5. Significant overlap within the visible range can be seen, and hence, the presence of such ubiquitous chromophores in relevant concentrations in the biofilm can impact PV quantum yield and thereby performance. Spectral data were used from photochemCAD (Taniguchi et al, 2018). ${ }^{104}$

plants, fungi, and some bacteria. ${ }^{107}$ All algae (and green plants) contain $\beta$-carotene, whereas purple sulfur and non-sulfur bacteria contain aliphatic and aryl-type carotenoids; green bacteria contain only aryl carotenoids. ${ }^{103}$ Among others, carotenoids absorb light energy and pass excitation energy to chlorophyll. These processes not only extend the energy range that can be harvested for photosynthesis but also increase competition for photons (Figure 2). In summary, competition for photons is inevitable, but the extent of competition both in terms of total photon influx and wavelengths preferentially absorbed depends on the colonization and maturation of SAB communities-issues that remain largely unknown.

\section{PHYSICAL SUBSTRATE BIODETERIORATION THAT AFFECTS PV LIFETIME}

Virtually, all of today's PV installations are based on glass substrates. Effects of glass biodeterioration (e.g., etching, pit corrosion, and leaching ${ }^{108}$ ) are well known. However, one may doubt that these would occur to a considerable extent during the anticipated lifetime of a PV installation (around two decades). Rather than affecting the glass substrate as a whole, one may nevertheless imagine microscopic etching of the surface, possibly facilitating SAB colonization during years or decades of outdoor exposure. In contrast, other approaches to embedding organic electronics are used and commerlized, ${ }^{109}$ and the production of transparent, flexible, and inexpensive thin-film PVs that can be deployed at large scale are typically prepared on PET or PEN films. If a barrier film is placed on both sides of a cell, PET can contribute to $\sim 90 \%$ of OPV weight. ${ }^{9}$ In comparison with glass, plastic products, such as PET, are softer materials and thus more vulnerable to microscopic damages (scratches, pinholes, etc.) during production and installation. A higher surface roughness and porosity also affect bio receptivity regarding colonization in ceramic building materials. ${ }^{101}$ Hence, plastic-encapsulated PV and glass-based PV may extensively differ as regards susceptibility to colonization. In addition, the initial colonization of heterotrophic microorganisms depends on the bioavailability of a carbon source, which may be provided by organic substances leaching from either the polymer matrix of a 
cell or additives, plasticizers and other impurities found in plastic-based, emerging thin-film PVs. Decaying biomass can then provide a rich medium on which communities (including complex organisms, such as plants, mosses, or lichens) may further develop.

The general resistance of plastics against microbial attack has been related to the fact that their presence in nature has not allowed for the evolution of appropriate microbial enzymatic systems for complete or fast degradation. Only recently, a pure strain that can use PET as its major energy and carbon source, hydrolyzing PET as well as an intermediate to monomeric terephthalic acid and ethylene glycol has been reported. ${ }^{110}$ An engineered enzyme was demonstrated to have even higher PET hydrolysis rates than do any known native enzyme, ${ }^{111}$ pointing to the limitations of PET degradation under natural conditions. The biodegradation of most synthetic plastics in the environment is a sequence of physicochemical degradation processes that act synergistically with biodegradation. UV degradation and thermal stress result in more hydrophilic, lowermolecular-weight derivatives that are ultimately accessible to microorganisms. The biodegradation of polymeric materials has been divided into four successive stages: (1) Microbes adhere to a surface, thereby altering surface properties (e.g., hydrophilicity); (2) additives (e.g., plasticizers) and monomers leach; (3) biogenic enzymes or radicals attack plastics and additives, thereby increasing brittleness; and (4) water accumulates and penetrates materials. ${ }^{112}$ Often, a combination of extra- and intracellular depolymerisation and hydrolytic enzymes are actively involved in such processes: exo-enzymes initially break down complex polymers that are too large to pass microbial membranes. The resultant lower-molecular-weight oligomers, dimers, and monomers may then encounter intracellular enzymes, thus undergoing further degradation. Note that abiotic hydrolysis, however, is a rate-limiting step that initiates the environmental degradation of PET and several other synthetic polymers. Hydrolytic degradation is favored at high temperatures, ${ }^{113}$ and hence, can occur on plastic PVs. Since environmental degradation of plastics is a result of the combined, synergistic action of physical (UV, thermal) and biological stressors (biodegradation), the question remains as to which extent degradation of plastic PVs in the field is accelerated in contrast to degradation by single stressors.

The alternating heating-cooling, freezing-thawing, or wetting-drying cycles that occur on plastic PVs can ease and accelerate biodeteriorative effects. Once challenged by increased brittleness, microbial filaments can penetrate materials, ${ }^{112}$ perturbing the physical integrity of a plastic substrate by generating (among other effects) high cellular pressure. For instance, the rice pathogen Magnaporthe grisea penetrates synthetic surfaces, such as poly(vinyl chloride) or Mylar'T, by generating pressures in excess of 8.0 Mpa (80 bars). ${ }^{114}$ Once cracks reach photoactive layers, a number of precipitation and/or solubilization reactions can occur and consequently decrease the lifetime of plastic PVs. Increased brittleness resulting in elevated water-gas permeability or even crack formation is not only detrimental to performance but can also release compounds encapsulated in PV modules to the environment (Figure 1). This problem is particularly critical when it comes to metal-based thin-film PV (perovskites, GaAs, CIGS, etc.). It was previously demonstrated that field-installed OPVs emit silver and zinc, with large peak concentrations occurring as soon as their physical integrity is breached. ${ }^{115}$

\section{ACTIVE LAYER BIODETERIORATION THAT AFFECTS PV LIFETIME}

As outlined above, a mature SAB on a PV installation can host a complex community of different trophic groups of organisms, ${ }^{72,116}$ producing a number of metabolic intermediates and end products that can affect the lifetime of PVs, especially those 


\section{$\boldsymbol{\infty}$ CellPress}

based on plastic. For instance, SRB use sulfate as a terminal electron acceptor in their respiratory chain, producing $\mathrm{H}_{2} \mathrm{~S}$, which can permeate through a variety of polymers, including (virgin) PET. $\mathrm{H}_{2} \mathrm{~S}$ is highly reactive toward a number of metals, so-called chalcophiles, thereby forming insoluble precipitates, such as $\mathrm{ZnS}\left(\mathrm{K}_{\mathrm{sp}}=2 \times 10^{-25}\right)$ or $\mathrm{Ag}_{2} \mathrm{~S}\left(6 \times 10^{-51}\right)$. Consequently, rapid sulfidation occurs, for instance, in nanoparticles of $\mathrm{Ag}$ and $\mathrm{ZnO}$ and from Sn stemming from ITO leachates. ${ }^{117-119}$ The biogenic production of $\mathrm{H}_{2} \mathrm{~S}$ requires only minute amounts of biofilms and sulfate (high reduction rates occurring down to $1 \mu \mathrm{M}=96 \mu \mathrm{g} / \mathrm{L}^{120}$ ). In perovskite thin-film $\mathrm{PVs}, \mathrm{H}_{2} \mathrm{~S}$ permeation could even induce degradation of the photoactive layer. Various lead salts, including $\mathrm{PbS}\left(\mathrm{K}_{\mathrm{sp}}=9 \times 10^{-29}\right)$, are fairly insoluble; hence, degradation of the perovskite structure via $\mathrm{Pb}$ precipitation would fully perturb $\mathrm{PV}$ performance.

Considering altered metal speciation is essential also from the point of PV failure and subsequent leaching. In the case of perovskite $\mathrm{PV}$, the low solubility product $\left(\mathrm{K}_{\mathrm{sp}}\right.$ $\left.\sim 10^{-8}\right)^{121}$ initially points to $\mathrm{Pbl}_{2}$ as a phase, controlling dissolved (and eventually bioavailable) $\mathrm{Pb}$ concentration. However, the presence of $\mathrm{H}_{2} \mathrm{~S}$ would result in even lower dissolved $\mathrm{Pb}$ concentrations at thermodynamic equilibrium. Moreover, carbonate and phosphate are omnipresent in the environment. $\mathrm{CO}_{2}$ from heterotrophic respiration dissolves in rainwater, providing a potential pathway for (bi)carbonate exposure on intact or damaged PV cells. Microbially released phosphate in the extracellular matrix can directly generate phosphatic species on a PV surface. Microbial carbonate and/or phosphate sources might lead to $\mathrm{Pb}$ immobilization via the formation of $\mathrm{PbCO}_{3}$ or $\mathrm{PbHPO}_{4}$ and further constrain $\mathrm{Pb}$ solubility yet shift equilibria toward perovskite dissolution. In contrast to silicate weathering on glass-based PV substrates, such biodeterioration processes transpire within a minimal time frame-possibly within the lifetime of a typical PV application. Unlike $\mathrm{H}_{2} \mathrm{~S}$ and $\mathrm{CO}_{2}$, organic acids released by bacteria and fungi may have a chelating, and thus, opposing effect on the fate of $\mathrm{Pb}$ in the environment. ${ }^{122,123}$ For instance, smallmolecular-weight acids of biogenic origin increase lead solubility via chelation. ${ }^{124}$ $\mathrm{Pb}$ is also known to readily form complexes with natural organic matter. ${ }^{125,126}$ Bacterial siderophore production can be enhanced by the presence of lead, ${ }^{127}$ which may, in turn, enhance the solubilization of other functional PV materials (e.g., $\left.\mathrm{TiO}_{2}{ }^{128}\right)$.

The transformation of metals when exposed to environmental media (e.g., perovskite to $\mathrm{Pbl}_{2}$ nanoparticles) underlines that simply quantifying dissolved $\mathrm{Pb}$ under classical damp-heat conditions might be an inappropriate proxy for the assessment of the environmental fate of leachates. Instead, a mandatory requirement would be to conduct tests in (model) natural waters and, possibly, waters that contain common microbial respiratory products (i.e., $\mathrm{H}_{2} \mathrm{~S}, \mathrm{CO}_{2}$, and organic acids). Cracks may potentially represent point sources for metal release, and thus, represent a challenge to product safety. Upon dissolution, sequestration within a biofilm ultimately determines environmental concentrations. Whatever metal is being used in PV, models that estimate risks need dissolved metal concentrations as an essential input. Thermodynamic modeling (e.g., in the form of $\mathrm{pE}$ versus $\mathrm{pH}$ diagrams) alone is insufficient to evaluate the latter because (1) most thermodynamic constants are defined for "pure" systems (i.e., systems with no complex organic matter in the form of intact or decaying biomass); (2) databases are often incomplete (particularly those on biotransformed species) or contradictory; and (3) conditions at thermodynamic equilibrium are considered. Thus, no conclusions can be drawn on kinetics, allowing for formed meta-stable phases as intermediary products. In fact, many biomineralized (induced or controlled) precipitates are meta-stable, often highly disordered phases that are stabilized against transformation into most thermodynamically stable species via biogenic molecules. ${ }^{129-131}$ 
In this regard, special attention should be given to perovskite PV, because these contain metals with well-documented ecotoxic histories (i.e., lead and its most common substitute, tin). Concerns have been raised regarding instant and complete methylammonium lead iodide (non-encapsulated) degradation upon contact with rain. ${ }^{132}$ The authors assumed that the formation of $\mathrm{Pbl}_{2}$ colloids explain the limited dissolved $\mathrm{Pb}$ concentrations and described this worst-case assessment as "highly undesirable" but "far from catastrophic." Using state-of-the-art analytical methods in examining trace metals, such as (single particle) ICP-MS, can provide the necessary tools for further elucidating the dissolution of inorganic PV layers. Understanding the fate and transport processes of contaminant emissions from emerging thin-film PVs is also expected to ultimately affect the overall environmental impact of renewable energy technology.

\section{CONCLUSION}

Renewable energy based on solar harvesting requires technologies that are long lasting, highly efficient energy converters that, at the same time minimize energy- and materialintensive production. Emerging thin-film PV technologies have improved in terms of initial longevity issues, but longer service times are mostly extrapolated on the basis of accelerated aging tests conducted in laboratories. These typically exclude biologically induced failure mechanisms known as biodeterioration, which perturb a range of inert materials (including glass and plastic PV substrates) and have not been properly addressed thus far in relation to thin-film solar cells. Intrinsic material properties (e.g., surface hydrophilicity, roughness, hardness, brittleness, gas permeability, substrate thickness, etc.) may result in the kind of deterioration exclusively occurring in plastic-based PVs. Therefore, plastic-based thin-film PVs may not live up to their promise as regards a lifetime under real-life, outdoor operating conditions. There is a need for simulations and tests to include biodeterioration effects. Only if SAB colonization of photovoltaics is understood on a fundamental level, one may be able to design suitable laboratory tests and simulations to predict "true" efficiencies and lifetimes in the field. Further, only polymers resistant to biodeterioration represent environmentally safe materials since they will prevent leaching of metals contained.

\section{ACKNOWLEDGMENTS}

This project has received funding from the European Union's Horizon 2020 framework program for research and innovation under grant agreement no 763977 of the PerTPV project.

\section{AUTHOR CONTRIBUTIONS}

Conceptualization, M.L., B.A.K., E.D.v.H., and F.C.K.; Writing-Original Draft, F.S., Y.-S.Z., G.A.d.R.B.; Writing - Review and Editing, F.S. with approval from all authors; Supervision, M.L., and A.S.; Project Administration, M.L.

\section{REFERENCES}

1. Griggs, D., Stafford-Smith, M., Gaffney, O., Rockström, J., Öhman, M.C., Shyamsundar, P., Steffen, W., Glaser, G., Kanie, N., and Noble, I. (2013). Policy: sustainable development goals for people and planet. Nature 495, 305-307.

2. Masson, G., and Kaizuka, I. (2018). Trends in Photovoltaic Applications 2018 (International Energy Agency). https://iea-pvps.org/wpcontent/uploads/2020/02/5319-iea-pvpsreport-2019-08-Ir.pdf.

3. Fraunhofer Institute for Solar Energy Systems (2016). Photovoltaics report. https://www.ise. fraunhofer.de/en/downloads-englisch/pdffiles-englisch/photovoltaics-report-slides. pdf.

4. Serrano-Luián, L., Espinosa, N., Abad, J., and Urbina, A. (2017). The greenest decision on photovoltaic system allocation. Renew. Energy 101, 1348-1356.

5. Haegel, N.M., Atwater, H., Barnes, T., Breyer, C., Burrell, A., Chiang, Y.M., De Wolf, S., Dimmler, B., Feldman, D., Glunz, S., et al. (2019). Terawatt-scale photovoltaics: transform global energy. Science 364, 836-838.
6. Kumar, M.H., Yantara, N., Dharani, S. Graetzel, M. Mhaisalkar, S., Boix, P.P and Mathews, N. (2013). Flexible, lowtemperature, solution processed $\mathrm{ZnO}-$ based perovskite solid state solar cells. Chem. Commun (Camb). 49, 1108911091.

7. Docampo, P., Ball, J.M., Darwich, M., Eperon, G.E., and Snaith, H.J. (2013). Efficient organometal trihalide perovskite planar-heterojunction solar cells on flexible polymer substrates. Nat. Commun. 4 2761. 
8. Galagan, Y., Rubingh, J.J.M., Andriessen, R., Fan, C., Blom, P.W.M., Veenstra, S.C., and Kroon, J.M. (2011). ITO-free flexible organic solar cells with printed current collecting grids. Sol. Energy Mater. Sol. Cells 95, 1339-1343.

9. Grossiord, N., Kroon, J.M., Andriessen, R., and Blom, P.W.M. (2012). Degradation mechanisms in organic photovoltaic devices. Org. Electron. 13, 432-456.

10. Gong, J., Darling, S.B., and You, F. (2015). Perovskite photovoltaics: life-cycle assessment of energy and environmental impacts. Energy Environ. Sci. 8, 1953-1968.

11. Celik, I., Song, Z., Cimaroli, A.J., Yan, Y., Heben, M.J., and Apul, D. (2016). Life Cycle Assessment (LCA) of perovskite PV cells projected from lab to fab. Sol. Energy Mater. Sol. Cells 156, 157-169.

12. Krebs, F.C., Espinosa, N., Hösel, M. Søndergaard, R.R., and Jørgensen, M. (2014). 25th anniversary article: rise to power-OPVbased solar parks. Adv. Mater. 26, 29-38.

13. Roldán-Carmona, C., Malinkiewicz, O., Soriano, A., Mínguez Espallargas, G.M. Garcia, A., Reinecke, P., Kroyer, T., Dar, M.I., Nazeeruddin, M.K., and Bolink, H.J. (2014). Flexible high efficiency perovskite solar cells. Energy Environ. Sci. 7, 994-997.

14. Cui, D., Yang, Z., Yang, D., Ren, X., Liu, Y., Wei, Q., Fan, H., Zeng, J., and Liu, S. (2016). Colortuned perovskite films prepared for efficient solar cell applications. J. Phys. Chem. C 120, $42-47$.

15. Sessolo, M., and Bolink, H.J. (2015). Solar cells. Perovskite solar cells join the major league. Science 350, 917.

16. Hwang, K., Jung, Y.S., Heo, Y.J., Scholes, F.H., Watkins, S.E., Subbiah, J., Jones, D.J., Kim, D.Y., and Vak, D. (2015). Toward large scale roll-to-roll production of fully printed perovskite solar cells. Adv. Mater. Weinheim 27, 1241-1247.

17. Ye, M., Hong, X., Zhang, F., and Liu, X. (2016). Recent advancements in perovskite solar cells: flexibility, stability and large scale. J. Mater. Chem. A 4, 6755-6771.

18. Correa-Baena, J.-P., Abate, A., Saliba, M. Tress, W., Jesper Jacobsson, T.J., Grätzel, M., and Hagfeldt, A. (2017). The rapid evolution of highly efficient perovskite solar cells. Energy Environ. Sci. 10, 710-727.

19. Green, M.A., Ho-Baillie, A., and Snaith, H.J. (2014). The emergence of perovskite solar cells. Nat. Photonics 8, 506-514.

20. Lotsch, B.V. (2014). New light on an old story: perovskites go solar. Angew. Chem. Int. Ed. Engl. 53, 635-637.

21. Green, M.A., Dunlop, E.D., Levi, D.H., HohlEbinger, J., Yoshita, M., and Ho-Baillie, A.W.Y. (2019). Solar cell efficiency tables, (version 54). Prog. Photovolt Res. Appl. 27, 565-575.

22. Espinosa, N., Hösel, M., Angmo, D., and Krebs, F.C. (2012). Solar cells with one-day energy payback for the factories of the future. Energy Environ. Sci. 5, 5117-5132.
23. Han, K., Xie, M., Zhang, L., Yan, L., Wei, J., Ji, G., Luo, Q., Lin, J., Hao, Y., and Ma, C.-Q. (2018). Fully solution processed semitransparent perovskite solar cells with spraycoated silver nanowires/ZnO composite top electrode. Sol. Energy Mater. Sol. Cells 185, 399-405.

24. Jiang, Z., Chen, X., Lin, X., Jia, X., Wang, J., Pan, L., Huang, S., Zhu, F., and Sun, Z. (2016). Amazing stable open-circuit voltage in perovskite solar cells using AgAl alloy electrode. Sol. Energy Mater. Sol. Cells 146, $35-43$.

25. Hösel, M., Angmo, D., Søndergaard, R.R., dos Reis Benatto, G.A. Carlé, J.E., Jørgensen, M. and Krebs, F.C. (2014). High-volume processed, ITO-free superstrates and substrates for roll-toroll development of organic electronics. Adv Sci (Weinh) 1, 1400002.

26. Haque, M.A., Sheikh, A.D., Guan, X., and Wu, T. (2017). Metal oxides as efficient charge transporters in perovskite solar cells. Adv. Energy Mater. 7, 1602803.

27. Shin, S.S., Lee, S.J., and Seok, S.I.I. (2019). Metal oxide charge transport layers for efficient and stable perovskite solar cells. Adv. Funct. Mater. 29, 1900455.

28. Choy, W.C.H., and Zhang, D. (2016). Solutionprocessed metal oxides as efficient carrier transport layers for organic photovoltaics. Small 12, 416-431.

29. Cheacharoen, R., Boyd, C.C., Burkhard, G.F. Leijtens, T., Raiford, J.A., Bush, K.A., Bent S.F., and McGehee, M.D. (2018) Encapsulating perovskite solar cells to withstand damp heat and thermal cycling. Sustain. Energy Fuels 2, 2398-2406.

30. Corsini, F., and Griffini, G. (2020). Recent progress in encapsulation strategies to enhance the stability of organometal halide perovskite solar cells. J. Phys. Energy 2.

31. Kim, Y.Y., Yang, T.Y., Suhonen, R., Välimäki, M., Maaninen, T., Kemppainen, A., Jeon, N.J., and Seo, J. (2019). Gravure-printed flexible perovskite solar cells: Toward Roll-To-Roll Manufacturing. Adv Sci (Weinh) 6, 1802094.

32. Seo, K.-W., Noh, Y.-J., Na, S.-I., and Kim, H.-K (2016). Random mesh-like Ag networks prepared via self-assembled Ag nanoparticles for ITO-free flexible organic solar cells. Sol. Energy Mater. Sol. Cells 155, 51-59.

33. Guo, F., Azimi, H., Hou, Y., Przybilla, T., Hu, M., Bronnbauer, C., Langner, S., Spiecker, E., Forberich, K., and Brabec, C.J. (2015). Highperformance semitransparent perovskite solar cells with solution-processed silver nanowires as top electrodes. Nanoscale 7, 1642-1649.

34. Zhang, X., Wu, J., Wang, J., Zhang, J., Yang Q., Fu, Y., and Xie, Z. (2016). Highly conductive PEDOT: PSS transparent electrode prepared by a post-spin-rinsing method for efficient ITO-free polymer solar cells. Sol. Energy Mater. Sol. Cells 144 143-149.

35. Vaagensmith, B., Reza, K.M., Hasan, M.N Elbohy, H., Adhikari, N., Dubey, A., Kantack, N., Gaml, E., and Qiao, Q. (2017). Environmentally friendly plasma-treated PEDOT: PSS as electrodes for ITO-free perovskite solar cells. ACS Appl. Mater. Interfaces 9, 35861-35870.

36. Sun, K., Li, P., Xia, Y., Chang, J., and Ouyang, J. (2015). Transparent conductive oxide-free perovskite solar cells with PEDOT: PSS as transparent electrode. ACS Appl. Mater. Interfaces 7, 15314-15320.

37. You, P., Liu, Z., Tai, Q., Liu, S., and Yan, F. (2015). Efficient semitransparent perovskite solar cells with graphene electrodes. Adv. Mater. 27, 3632-3638.

38. Tirado, J., Ramirez, D., Betancur, R., and Jaramillo, F. (2018). Low-cost semitransparent copper sulfide electrode for indium-tin-oxide-free perovskite solar cells. Thin Solid Films 662, 90-96.

39. Jung, H.S., and Park, N.G. (2015). Perovskite solar cells: from materials to devices. Small 11. $10-25$.

40. Zimmermann, Y.S., Schäffer, A., Hugi, C., Fent, K., Corvini, P.F.-X., and Lenz, M. (2012). Organic photovoltaics: potential fate and effects in the environment. Environ. Int. 49, 128-140.

41. McMahon, T.J. (2004). Accelerated testing and failure of thin-film PV modules. Prog. Photovolt: Res. Appl. 12, 235-248.

42. Yang, J., and Kelly, T.L. (2017). Decomposition and cell failure mechanisms in lead halide perovskite solar cells. Inorg. Chem. 56, 92-101.

43. Roesch, R. Faber, $T$, von Hauff, E., Brown, T.M., Lira-Cantu, M., and Hoppe, H. (2015) Procedures and practices for evaluating thinfilm solar cell stability. Adv. Energy Mater. 5, 1501407.

44. Jørgensen, M., Norrman, K., and Krebs, F.C. (2008). Stability/degradation of polymer solar cells. Sol. Energy Mater. Sol. Cells 92, 686-714.

45. Zimmermann, E., Wong, K.K., Müller, M., Hu H., Ehrenreich, P., Kohlstädt, M., Würfel, U., Mastroianni, S., Mathiazhagan, G., Hinsch, A., et al. (2016). Characterization of perovskite solar cells: towards a reliable measurement protocol. APL Mater 4, 091901.

46. Khenkin, M.V., Katz, E.A., Abate, A., Bardizza, G., Berry, J.J., Brabec, C., Brunetti, F., Bulović, V., Burlingame, Q., Di Carlo, A., et al. (2020). Consensus statement for stability assessment and reporting for perovskite photovoltaics based on ISOS procedures. Nat. Energy 5 $35-49$.

47. Khenkin, M.V., Anoop, K.M., Visoly-Fisher, I., Galagan, Y., Di Giacomo, F., Patil, B.R., Sherafatipour, G., Turkovic, V., Rubahn, H.-G., Madsen, M., et al. (2018). Reconsidering figures of merit for performance and stability of perovskite photovoltaics. Energy Environ. Sci. 11, 739-743.

48. Zhang, Y., Samuel, I.D.W., Wang, T., and Lidzey, D.G. (2018). Current status of outdoor lifetime testing of organic photovoltaics. Adv Sci (Weinh) 5, 1800434.

49. Hacke, P., Spataru, S., Terwilliger, K., Perrin, G., Glick, S., Kurtz, S., and Wohlgemuth, J. (2015). Accelerated testing and modeling of potential-induced degradation as a function of temperature and relative humidity. IEEE $J$. Photovoltaics 5, 1549-1553. 
50. Meng, L., You, J., and Yang, Y. (2018). Addressing the stability issue of perovskite solar cells for commercial applications. Nat. Commun. 9, 5265

51. Commission, I.-I.E., et al. (2016) lec 61215-1-3. https://webstore.iec.ch/publication/29787.

52. Reese, M.O., Gevorgyan, S.A., Jørgensen, M., Bundgaard, E., Kurtz, S.R., Ginley, D.S., Olson D.C., Lloyd, M.T., Morvillo, P., Katz, E.A., et al. (2011). Consensus stability testing protocols for organic photovoltaic materials and devices. Sol. Energy Mater. Sol. Cells 95, 1253-1267.

53. Corazza, M., Krebs, F.C., and Gevorgyan, S.A. (2015). Lifetime of organic photovoltaics: linking outdoor and indoor tests. Sol. Energy Mater. Sol. Cells 143, 467-472.

54. Gevorgyan, S.A., Zubillaga, O., de Seoane, J.M.V., Machado, M., Parlak, E.A., Tore, N., Voroshazi, E., Aernouts, T., Müllejans, H., Bardizza, G., et al. (2014). Round robin performance testing of organic photovoltaic devices. Renew. Energy 63, 376-387.

55. Manceau, M., Rivaton, A., Gardette, J.-L., Guillerez, S., and Lemaître, N. (2011). Lightinduced degradation of the P3HT-based solar cells active layer. Sol. Energy Mater. Sol. Cells 95, 1315-1325.

56. Andreasen, B., Tanenbaum, D.M., Hermenau, M., Voroshazi, E., Lloyd, M.T., Galagan, Y. Zimmernann, B., Kudret, S., Maes, W., Lutsen, L., et al. (2012). TOF-SIMS investigation of degradation pathways occurring in a variety of organic photovoltaic devices-the ISOS-3 inter-laboratory collaboration. Phys. Chem. Chem. Phys. 14, 11780-11799.

57. Berhe, T.A., Su, W.-N., Chen, C.-H., Pan, C.-J., Cheng, J.-H., Chen, H.-M., Tsai, M.-C., Chen, L.-Y., Dubale, A.A., and Hwang, B.-J. (2016). Organometal halide perovskite solar cells: degradation and stability. Energy Environ. Sci. 9, 323-356.

58. Niu, G., Guo, X., and Wang, L. (2015). Review of recent progress in chemical stability of perovskite solar cells. J. Mater. Chem. A 3, 8970-8980.

59. De Rossi, F., Barbé, J., Tanenbaum, D.M. Cinà, L., Castriotta, L.A., Stoichkov, V., Wei, Z., Tsoi, W.C., Kettle, J., Sadula, A., et al. (2020). An interlaboratory study on the stability of allprintable hole transport material-free perovskite solar cells. Energy Technol. https://doi.org/10.1002/ente.202000134.

60. Larsen-Olsen, T.T., Machui, F., Lechene, B., Berny, S., Angmo, D., Søndergaard, R. Blouin, N., Mitchell, W., Tierney, S., Cull, T. et al. (2012). Round-robin studies as a method for testing and validating high-efficiency ITOfree polymer solar cells based on roll-to-rollcoated highly conductive and transparent flexible substrates. Adv. Energy Mater. 2, 1091-1094.

61. Corazza, M., García-Valverde, R., Dam, H.F. Madsen, M.V., Hösel, M., Benatto, G.AdR. Beliatis, M.J., Pastorelli, F., Veenstra, S., Knelissen, G., et al. (2019). Compact multifunctional source-meter system for characterisation of laboratory-scale solar cell devices. Meas. Sci. Technol. 30, 035901.

62. Jones, R.K. (2019). Solving the soiling problem for solar power systems. Joule 3, 2298-2300.
63. Einhorn, A., Micheli, L., Miller, D.C., Simpson, L.J., Moutinho, H.R., To, B., Lanaghan, C.L., Muller, M.T., Toth, S., John, J.J., et al. (2018) Evaluation of soiling and potential mitigation approaches on photovoltaic glass. IEEE J. Photovoltaics 9, 233-239.

64. Smestad, G.P., Germer, T.A., Alrashidi, H., Fernández, E.F., Dey, S., Brahma, H., Sarmah, N., Ghosh, A., Sellami, N., Hassan, I.A.I., et al. (2020). Modelling photovoltaic soiling losses through optical characterization. Sci. Rep. 10, $1-13$.

65. Ilse, K.K., Figgis, B.W., Naumann, V. Hagendorf, C., and Bagdahn, J. (2018) Fundamentals of soiling processes on photovoltaic modules. Renew. Sustain. Energy Rev. 98, 239-254.

66. Mejia, F.A., and Kleissl, J. (2013). Soiling losses for solar photovoltaic systems in California. Sol. Energy 95, 357-363.

67. Appels, R., Lefevre, B., Herteleer, B., Goverde, H., Beerten, A., Paesen, R., De Medts, K., Driesen, J., and Poortmans, J. (2013). Effect of soiling on photovoltaic modules. Sol. Energy 96, 283-291.

68. Piliougine, M., Cañete, C., Moreno, R., Carretero, J., Hirose, J., Ogawa, S., and Sidrach-de-Cardona, M. (2013). Comparative analysis of energy produced by photovoltaic modules with anti-soiling coated surface in arid climates. Appl. Energy 112, 626-634.

69. Isbilir, K., Lisco, F., Womack, G., Abbas, A., and Walls, J.M. (2018). Testing of an antisoiling coating for PV module cover glass. In IEEE 7th World Conference on Photovoltaic Energy Conversion (WCPEC) (A Joint Conference of 45th IEEE PVSC, 28th PVSEC \& 34th EU PVSEC) 2018, pp. 3426-3431.

70. Costa, S.C.S., Diniz, A.S.A.C., and Kazmerski, L.L. (2016). Dust and soiling issues and impacts relating to solar energy systems: literature review update for 2012-2015. Renew. Sustain. Energy Rev. 63, 33-61.

71. Toth, S., Muller, M., Miller, D.C., Moutinho, H., To, B., Micheli, L., Linger, J., Engtrakul, C., Einhorn, A., and Simpson, L. (2018). Soiling and cleaning: initial observations from 5-year photovoltaic glass coating durability study. Sol. Energy Mater. Sol. Cells 185, 375-384.

72. Martin-Sanchez, P.M., Gebhardt, C., Toepel, J., Barry, J., Munzke, N., Günster, J., and Gorbushina, A.A. (2018). Monitoring microbial soiling in photovoltaic systems: a qPCR-based approach. Int. Biodeterior. Biodegrad. 129, 13-22.

73. Noack-Schönmann, S., Spagin, O., Gründer K.-P., Breithaupt, M., Günter, A., Muschik, B., and Gorbushina, A.A. (2014). Sub-aerial biofilms as blockers of solar radiation: spectral properties as tools to characterise materialrelevant microbial growth. Int. Biodeterior. Biodegrad. 86, 286-293.

74. Villa, F., and Cappitelli, F. (2019). The ecology of subaerial biofilms in dry and inhospitable terrestrial environments. Microorganisms 7, 380.

75. Gilbert, J.A., and Stephens, B. (2018). Microbiology of the built environment. Nat. Rev. Microbiol. 16, 661-670.
76. Gorbushina, A.A. (2007). Life on the rocks. Environ. Microbiol. 9, 1613-1631.

77. Flemming, H.C., Wingender, J., Szewzyk, U., Steinberg, P., Rice, S.A., and Kjelleberg, S. (2016). Biofilms: an emergent form of bacterial life. Nat. Rev. Microbiol. 14, 563-575.

78. Chertov, O. Gorbushina, A., and Deventer, B. (2004). A model for microcolonial fungi growth on rock surfaces. Ecol. Modell. 177, 415-426.

79. Bharti, A., Velmourougane, K., and Prasanna, R. (2017). Phototrophic biofilms: diversity, ecology and applications. J. Appl. Phycol. 29, 2729-2744.

80. Breitenbach, R., Silbernagl, D., Toepel, J., Sturm, H., Broughton, W.J., Sassaki, G.L., and Gorbushina, A.A. (2018). Corrosive extracellular polysaccharides of the rockinhabiting model fungus Knufia Petricola. Extremophiles 22, 165-175.

81. Gu, J.-D., Ford, T.E., Berke, N.S., and Mitchell, R. (1998). Biodeterioration of concrete by the fungus Fusarium. Int. Biodeterior. Biodegrad. 41, 101-109.

82. Ortega-Calvo, J.J., Hernandez-Marine, M. and Sáiz-Jiménez, C. (1991). Biodeterioration of building materials by cyanobacteria and algae. Int. Biodeterior. 28, 165-185.

83. Coutinho, M.L., Miller, A.Z., and Macedo, M.F. (2015). Biological colonization and biodeterioration of architectural ceramic materials: an overview. J. Cult. Herit. 16 759-777.

84. Brehm, U., Gorbushina, A., and Mottershead, D. (2005). The role of microorganisms and biofilms in the breakdown and dissolution of quartz and glass. Palaeogeography Palaeoclimatology Palaeoecology 219, 117-129.

85. Gadd, G.M. (2017). Geomicrobiology of the built environment. Nat. Microbiol. 2, 16275.

86. Huang, S., Bergonzi, C., Schwab, M., Elias, M. and Hicks, R.E. (2019). Evaluation of biological and enzymatic quorum quencher coating additives to reduce biocorrosion of steel. PLoS One 14, e0217059.

87. Heitz, E., Flemming, H.-C., and Sand, W. (1996). Economic and Technical Overview. In Microbially Influenced Corrosion of Materials: Scientific and Engineering Aspects (Springer).

88. Mansfield, E., Sowards, J.W., and CrookesGoodson, W.J. (2015). Findings and recommendations from the NIST Workshop on alternative fuels and materials: biocorrosion. J. Res. Natl. Inst. Stand. Technol. 120, 28-36.

89. Shirakawa, M.A., Zilles, R., Mocelin, A., Gaylarde, C.C., Gorbushina, A., Heidrich, G. Giudice, M.C., Del Negro, G.M.B., and John, V.M. (2015). Microbial colonization affects the efficiency of photovoltaic panels in a tropical environment. J. Environ. Manage. 157. 160-167.

90. Dorado-Morales, P. Vilanova, C., Peretó, J. Codoñer, F.M., Ramón, D., and Porcar, M. (2016). A highly diverse, desert-like microbial biocenosis on solar panels in a Mediterranean city. Sci. Rep. 6, 29235. 
91. Porcar, M., Louie, K.B., Kosina, S.M., Van Goethem, M.W., Bowen, B.P., Tanner, K., and Northen, T.R. (2018). Microbial ecology on solar panels in Berkeley, CA, United States. Front. Microbiol. 9, 3043.

92. Ilse, K., Khan, M.Z., Voicu, N., Naumann, V., Hagendorf, C., and Bagdahn, J. (2019). Advanced performance testing of anti-soiling coatings- part II: particle-size dependent analysis for physical understanding of dust removal processes and determination of adhesion forces. Sol. Energy Mater. Sol. Cells 202, 110049.

93. Ambika Manirajan, B., Ratering, S., Rusch, V., Schwiertz, A., Geissler-Plaum, R., Cardinale, M., and Schnell, S. (2016). Bacterial microbiota associated with flower pollen is influenced by pollination type, and shows a high degree of diversity and species-specificity. Environ. Microbiol. 18, 5161-5174.

94. Long, L., Zhu, H., Yao, Q., and Ai, Y. (2008). Analysis of bacterial communities associated with spores of gigaspora margarita and gigaspora Rosea. Plant Soil 310, 1-9.

95. Zhang, Q., Acuña, J.J., Inostroza, N.G., Mora, M.L., Radic, S., Sadowsky, M.J., and Jorquera, M.A. (2019). Endophytic bacterial communities associated with roots and leaves of plants growing in chilean extreme environments. Sci. Rep. 9, 4950.

96. Zanardini, E., May, E., Purdy, K.J., and Murrell, J.C. (2019). Nutrient cycling potential within microbial communities on culturally important stoneworks. Environ. Microbiol. Rep. 11, 147-154.

97. Villa, F., Vasanthakumar, A., Mitchell, R., and Cappitelli, F. (2015). RNA-based molecular survey of biodiversity of limestone tombstone microbiota in response to atmospheric sulphur pollution. Lett. Appl. Microbiol. 60, 92-102.

98. Flemming, H.C., and Wingender, J. (2010) The biofilm matrix. Nat. Rev. Microbiol. 8, 623-633.

99. Jesus, M.A.M.Ld, Timò, G., Agustín-Sáenz, C., Braceras, I., Cornelli, M., and Ferreira, AdM. (2018). Anti-soiling coatings for solar cell cover glass: climate and surface properties influence. Sol. Energy Mater. Sol. Cells 185, 517-523.

100. Tong, Y., and Lighthart, B. (1997). Solar radiation is shown to select for pigmented bacteria in the ambient outdoor atmosphere. Photochem. Photobiol. 65, 103-106.

101. Vázquez-Nion, D., Silva, B., and Prieto, B. (2018). Influence of the properties of granitic rocks on their bioreceptivity to subaerial phototrophic biofilms. Sci. Total Environ. 610611, 44-54.

102. Vázquez-Nion, D., Troiano, F., Sanmartín, P., Valagussa, C., Cappitelli, F., and Prieto, B. (2018). Secondary bioreceptivity of granite: effect of salt weathering on subaerial biofilm growth. Mater. Struct. 51, 158.

103. Moat, A.G., Foster, J.W., and Spector, M.P. (2003). Microbial Physiology (John Wiley \& Sons).

104. Taniguchi, M., Du, H., and Lindsey, J.S. (2018). PhotochemCAD 3: diverse modules for photophysical calculations with multiple spectral databases. Photochem. Photobiol. 94, 277-289.

105. Nosanchuk, J.D., Stark, R.E., and Casadevall A. (2015). Fungal melanin: what do we know about structure? Front. Microbiol. 6, 1463.

106. Mohammadi, M., Burbank, L., and Roper, M.C. (2012). Biological role of pigment production for the bacterial phytopathogen Pantoea stewartii subsp. stewartii. Appl. Environ. Microbiol. 78, 6859-6865.

107. Narsing Rao, M.P., Xiao, M., and Li, W.J (2017). Fungal and bacterial pigments: secondary metabolites with wide applications. Front. Microbiol. 8, 1113.

108. Drewello, R., and Weissmann, R. (1997). Microbially influenced corrosion of glass. Appl. Microbiol. Biotechnol. 47, 337-346.

109. Yu, D., Yang, Y.-Q., Chen, Z., Tao, Y., and Liu, Y.-F. (2016). Recent progress on thin-film encapsulation technologies for organic electronic devices. Opt. Commun. 362, 43-49.

110. Yoshida, S., Hiraga, K., Takehana, T., Taniguchi, I., Yamaji, H., Maeda, Y., Toyohara, K., Miyamoto, K., Kimura, Y., and Oda, K. (2016). A bacterium that degrades and assimilates poly (ethylene terephthalate) Science 351, 1196-1199.

111. Tournier, V., Topham, C.M., Gilles, A., David, B., Folgoas, C. Moya-Leclair, E., Kamionka, E., Desrousseaux, M.L., Texier, H., Gavalda, S., et al. (2020). An engineered PET depolymerase to break down and recycle plastic bottles. Nature 580, 216-219.

112. Flemming, H.-C. (1998). Relevance of biofilms for the biodeterioration of surfaces of polymeric materials. Polym. Degrad. Stab. 59, 309-315.

113. Kint, D., and Muñoz-Guerra, S. (1999). A review on the potential biodegradability of poly (ethylene terephthalate). Polym. Int. 48, 346-352.

114. Howard, R.J., Ferrari, M.A., Roach, D.H., and Money, N.P. (1991). Penetration of hard substrates by a fungus employing enormous turgor pressures. Proc. Natl. Acad. Sci. USA 88, 11281-11284.

115. Zimmermann, Y.S., Schäffer, A., Corvini, P.F.-X., and Lenz, M. (2013). Thin-film photovoltaic cells: long-term metal(loid) leaching at their end-of-life. Environ. Sci. Technol. 47, 13151-13159.

116. Ilse, K., Khan, M.Z., Voicu, N., Naumann, V., Hagendorf, C., and Bagdahn, J. (2019) Advanced performance testing of anti-soiling coatings-part I: sequential laboratory test methodology covering the physics of natural soiling processes. Sol. Energy Mater. Sol. Cells 202, 110048

117. Kaegi, R., Voegelin, A., Ort, C., Sinnet, B., Thalmann, B., Krismer, J., Hagendorfer, $H_{\text {.. }}$ Elumelu, M., and Mueller, E. (2013). Fate and transformation of silver nanoparticles in urban wastewater systems. Water Res 47, 3866-3877.

118. Ma, R., Levard, C., Michel, F.M., Brown, G.E., Jr., and Lowry, G.V. (2013). Sulfidation mechanism for zinc oxide nanoparticles and the effect of sulfidation on their solubility. Environ. Sci. Technol. 47, 2527-2534.
119. Li, Y., Liu, Z., Li, Q., Liu, Z., and Zeng, L. (2011). Recovery of indium from used indium-tin oxide (ITO) targets. Hydrometallurgy 105, 207-212.

120. Tarpgaard, I.H., Røy, H., and Jørgensen, B.B. (2011). Concurrent low-and high-affinity sulfate reduction kinetics in marine sediment. Geochim. Cosmochim. Acta 75, 2997-3010.

121. Green, D.B., Rechtsteiner, G., and Honodel, A. (1996). Determination of the thermodynamic solubility product of $\mathrm{Pbl} 2$ assuming nonideal behavior: an analytical chemistry experiment. J. Chem. Educ. 73, 789.

122. Gadd, G.M. (1999). Fungal production of citric and oxalic acid: importance in metal speciation, physiology and biogeochemical processes. Adv. Microb. Physiol. 41, 47-92.

123. Singh, R., Mittal, A., Kumar, M., and Mehta, P.K. (2017). Organic acids: an overview on microbial production. Int. J. Adv. Biotechnol. Res. 8, 104-111.

124. Yang, T., and Hodson, M.E. (2018) Investigating the potential of synthetic humiclike acid to remove metal ions from contaminated water. Sci. Total Environ. 635, 1036-1046.

125. Bai, H., Wei, S., Jiang, Z., He, M., Ye, B., and Liu, G. (2019). Pb (II) bioavailability to algae (Chlorella pyrenoidosa) in relation to its complexation with humic acids of different molecular weight. Ecotoxicol. Environ. Saf. 167, 1-9.

126. Lamelas, C., and Slaveykova, V.I. (2007) Comparison of $\mathrm{Cd}(\mathrm{II}), \mathrm{Cu}(\mathrm{II})$, and $\mathrm{Pb}$ (II) biouptake by green algae in the presence of humic acid. Environ. Sci. Technol. 41,41724178.

127. Naik, M.M., and Dubey, S.K. (2011). Leadenhanced siderophore production and alteration in cell morphology in a Pb-resistant Pseudomonas aeruginosa strain 4EA. Curr. Microbiol. 62, 409-414.

128. Baramov, T., Keijzer, K., Irran, E., Mösker, E., Baik, M.H., and Süssmuth, R. (2013). Synthesis and structural characterization of hexacoordinate silicon, germanium, and titanium complexes of the E. coli siderophore enterobactin. Chemistry 19, 10536-10542.

129. Lenz, M., Kolvenbach, B., Gygax, B., Moes, S., and Corvini, P.F.X. (2011). Shedding light on selenium biomineralization: proteins associated with bionanominerals. Appl. Environ. Microbiol. 77, 4676-4680.

130. Weiner, S., and Addadi, L. (2011). Crystallization pathways in biomineralization. Annu. Rev. Mater. Res. 41, 21-40.

131. Gower, L.B. (2008). Biomimetic model systems for investigating the amorphous precursor pathway and its role in biomineralization. Chem. Rev. 108, 4551-4627.

132. Hailegnaw, B., Kirmayer, S., Edri, E., Hodes, G., and Cahen, D. (2015). Rain on methylammonium lead iodide based perovskites: possible environmental effects of perovskite solar cells. J. Phys. Chem. Lett. 6, 1543-1547. 